\title{
Primary carcinoid tumor in the external auditory canal
}

\author{
Dong Hae Chung ${ }^{1 *}$, Gyu Cheol Han ${ }^{2 *}$, Na Rae Kim ${ }^{1}$ \\ Departments of ${ }^{1}$ Pathology and ${ }^{2}$ Otolaryngology, Gil Medical Center, Gachon University College of Medicine, Incheon, Korea
}

\begin{abstract}
A 39-year-old man visited the department of otolaryngology due to an ongoing hearing disturbance that had lasted for 1 year. Temporal bone computed tomography revealed soft tissue density nearly obliterating the left external auditory canal (EAC). The mass was composed of sheets of round tumor cells containing moderate amounts of fine granular cytoplasm and salt and pepper chromatin. Neither mitosis nor necrosis was found. The Ki-67 proliferation index was less than $2 \%$. Cells were positive for CD56 and synaptophysin but negative for chromogranin, cytokeratin (CK) 20, and CK7. Based on these findings, the tumor was diagnosed as a carcinoid tumor, well differentiated neuroendocrine carcinoma, grade 1 (G1) according to current World Health Organization (WHO) classification of head and neck tumors; and a neuroendocrine tumor, G1 according to neuroendocrine neoplasm (NEN)-2018 WHO standard classification. He remained free of local recurrence and metastasis after 20 months of follow up. To date, only six cases of primary NENs in the EAC have been reported. Metastatic tumor should be included in the differential diagnoses. Because of its rarity, the prognosis and treatment have not yet been clarified.
\end{abstract}

Key Words: Carcinoid tumor; Neuroendocrine neoplasms; Carcinoma, neuroendocrine; External auditory canal

Received: August 5, 2019 Revised: October 21, 2019 Accepted: November 7, 2019

Corresponding Author: Na Rae Kim, MD, PhD, Department of Pathology, Gil Medical Center, Gachon University College of Medicine, 21 Namdong-daero 774 beon-gil, Namdong-gu, Incheon 21565, Korea

Tel: +82-32-460-3073, Fax: +82-32-460-2394, E-mail: naraech@empal.com

*Dong Hae Chung and Gyu Cheol Han contributed equally to this work.

Neuroendocrine neoplasms (NENs) exhibit epithelial and neuroendocrine features derived from the primitive common precursor cells of the neural crest. NENs may occur throughout the body, but the gastrointestinal tract is the most commonly encountered location. Head and neck locations, especially those within the ear, are rare. A literature search identified fewer than 30 cases of NEN in the middle ear [1], with cases of middle ear adenoma, neuroendocrine adenoma of the middle ear, or amphicrine adenoma. However, only six cases of NEN of the external auditory canal (EAC) have been reported [2-7].

Here, we report an extremely rare case of a carcinoid, well differentiated neuroendocrine tumor (NET) grade 1 (G1) occurring in the EAC [8]. In addition, we review the new uniform 2018-World Health Organization (WHO) classification of NENs proposed for consistent taxonomy [9].

\section{CASE REPORT}

A 39-year-old Korean man presented at the department of otolaryngology complaining of left hearing disturbance and tinnitus for one year. Physical examination revealed an EAC filled with a rubbery hard mass (Fig. 1A). Temporal bone computed tomography (CT) depicted soft tissue density in and almost obliterating the left EAC (Fig. 1B) with bone erosion and extension beyond the EAC. Initially, otitis externa and a benign tumorous condition were included in the differential diagnoses. An endaural incision was performed under local anesthesia, and widening of the inferior and posterior walls of the EAC was achieved by drilling. The mass nearly obliterated the EAC and was located near the tympanic membrane, which remained intact. Microdissection was performed using a micro scissors.

Grossly, the excised ovoid mass measured $0.9 \times 0.8 \times 0.5 \mathrm{~cm}$ and had a hard rubbery texture. Microscopically, the mass was composed of round tumor cells that formed loose cohesive cords, sheets, or trabecula of glandular architecture (Fig. 2A). Tumor cells contained abundant amounts of fine granular cytoplasm and small nucleoli with salt and pepper nuclear chromatin. Endolymphatic and vascular tumor emboli were observed, but neither 


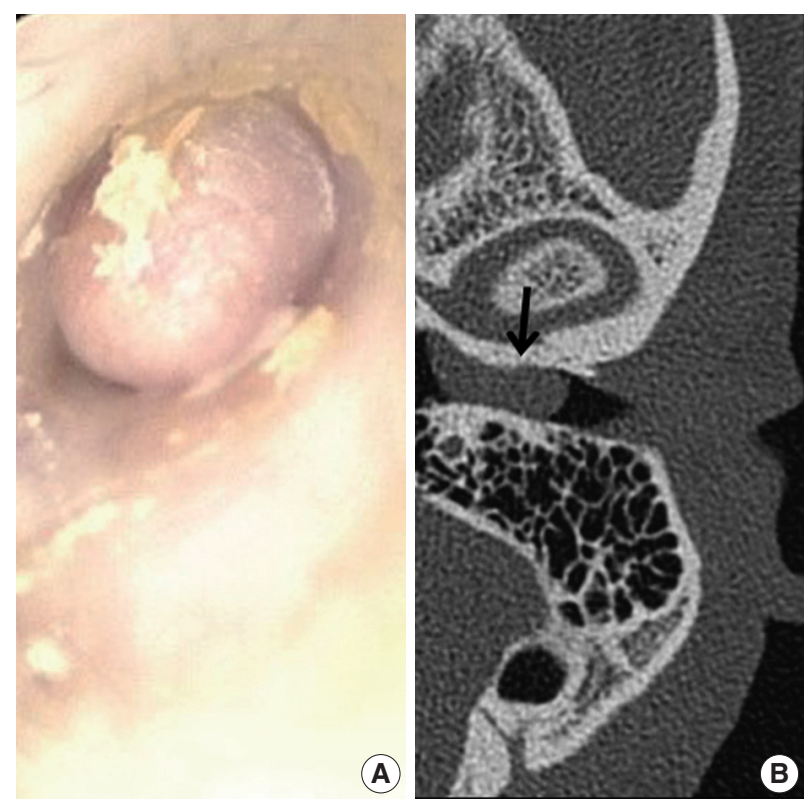

Fig. 1. Myringoscopy revealed a grayish-colored firm mass obliterating the left external auditory canal (A), and temporal bone computed tomography revealed soft tissue density (arrow) at the external auditory canal (B).
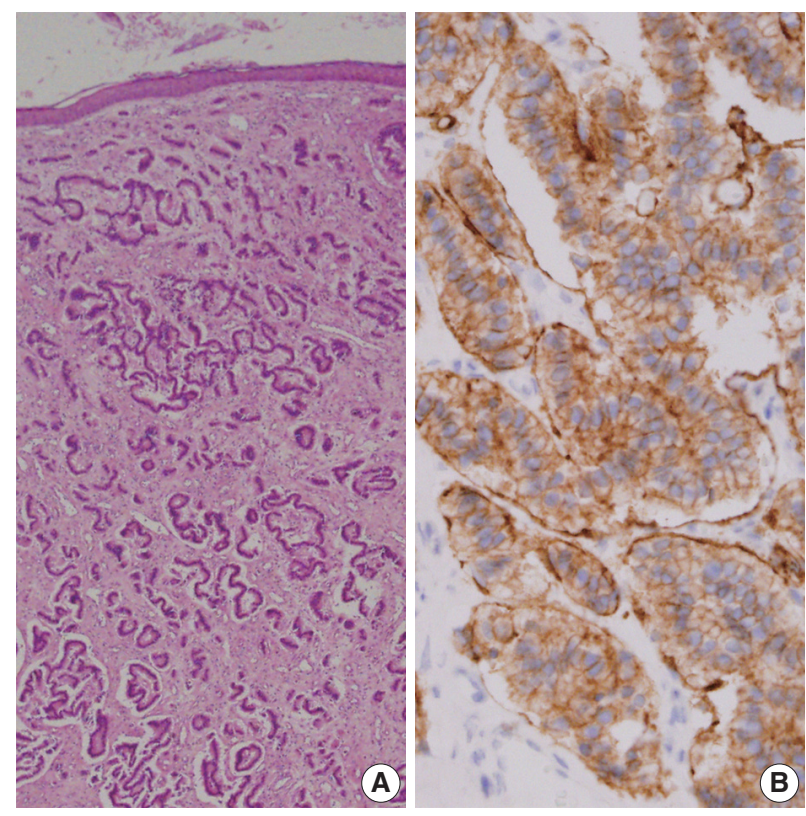

Fig. 2. Low-power view revealed small uniform tumor cells arranged in cords, trabecular, and nested patterns (A). Tumor cells were strongly positive for synaptophysin (B).

mitosis nor necrosis was evident. Immunohistochemically, tumor cells were positive for synaptophysin (prediluted, DAK-SYNAP, Dako, Glostrup, Denmark) (Fig. 2B, left) and CD56 (1:100, CD564, Novocastra, Newcastle upon Tyne, UK) (Fig. 2B, right) but negative for chromogranin (1:100, DAK-A3, Dako),
CK20 (1:100, KS 20.8, Dako), and CK7 (1:100, OV-TL 12/30, Dako). The Ki-67 (1:100, MIB-1, Dako) proliferation index was less than $2 \%$. Accordingly, the tumor was diagnosed as a carcinoid tumor with no necrosis or mitosis; neuroendocrine carcinoma (NEC) G1 according to the 4th edition of WHO classification of head and neck tumors and NET G1-2018 WHO according to the uniform standard classification framework.

To exclude metastatic tumor from another site, esophagogastroscopy, colonoscopy, and abdominopelvic CT; torso positron emission tomography (PET); and a bone scan were performed, but there was no evidence of a primary or metastatic tumor.

Hearing sensation was recovered after surgery, and the patient showed no systemic symptom, including those of carcinoid syndrome. Radiation and chemotherapy were withheld. Instead, we followed the patient with annual PET and head and neck CT imaging. During the 20 months of follow up, he showed no local recurrence or metastasis.

\section{Ethics statement}

Approval was obtained from our Institutional Review Board (No. GBIRB-2019-238) for publication of this case report with a waiver of informed consent.

\section{DISCUSSION}

Most malignant tumors arising from the EAC are primary tumors, among which squamous cell carcinoma and basal cell carcinoma are the most common; others include malignant melanoma, lymphoma, and ceruminous gland carcinoma. Few reports on metastasis to the EAC from extra-auditory malignancies are reported in the literature [10]. Primary middle ear adenoma extending to the EAC has been occasionally reported [1], but only six cases of NENs isolated to the EAC were reported to date [2-7]. NENs contain epithelial and neuroendocrine components and originate from primitive undifferentiated pluripotential stem cells and neural crest cells distributed throughout the body, especially in the gut and bronchopulmonary system. However, the origin of NENs of EAC remains uncertain, like those of skin, because there seem to be no neuroendocrine cells in normal skin except for Merkel cells [8]. Cells of neural crest origin and epidermal origin should be considered, but further study is required to elucidate the origins of EAC and skin NENs.

Clinically, unlike NENs of the bronchopulmonary tract or pancreas, the typical carcinoid syndrome symptoms of flushing or diarrhea are uncommon in cases of cutaneous or EAC NEN [11]. Previously reported EAC NENs have been associated with 
unilateral conductive hearing loss, ear fullness, tinnitus, and dizziness. Because of its rarity, the NEN of the EAC in the present case was indistinguishable from its metastatic counterpart by morphology alone [8].

According to the 4th edition of WHO classification of head and neck tumors, NENs are categorized into well-differentiated (carcinoid, G1), moderately differentiated (atypical carcinoid, grade 2 [G2]), and poorly differentiated (small and large cell) NECs [8]. NETs arising in the head and neck are histologically classified as carcinoid tumors including well-differentiated NETs (NEC G1), atypical carcinoid tumors (moderately-differentiated NEC or NEC G2), poorly-differentiated or high-grade NECs (including small cell carcinomas and Merkel cell carcinomas [MCCs]), and mixed tumor-like adenocarcinoma $[1,11,12]$. Mitotic count and necrosis under light microscopy are important in grading: NENs lacking necrosis and low mitosis $(<2 / 10$ high-power fields [HPFs]) belong to NECs G1; NENs showing necrosis and/or mitosis (2-10 mitoses/10 HPFs) are categorized as NECs G2; and NENs showing necrosis and high mitotic rate (> 10 mitoses/10 HPFs) are categorized as NECs grade 3 (G3). Those are collectively named NENs including well-differentiat- ed and moderately differentiated NECs defined as NETs of G1 and G2, respectively, and the poorly differentiated NECs as small and large cell NECs in NEN-2018 WHO [9]. This new, common, and standardized classification of NENs of all organs is recommended to be used in a pathologic report as follows. Firstly, the parameters used for grading (mitotic count, Ki-67 labeling index [\%], and necrosis) be stated clearly; secondly, the site-specific tumor nomenclature must be used according to current WHO classifications; and finally, the uniform classification framework is added in brackets, e.g., NEN-WHO 2018.

In review of the seven reported cases of EAC NENs, including the present case, we categorized four cases as NECs (MCCs) and three were well differentiated NENs. Even if NEN of the ear has non-high-grade histology and an indolent biological behavior, metastatic potential may exist, and the tumor may recur [7]. The recurrence rate of middle ear NEN has been reported to be up to $15 \%$ [13]. Recently, one case of low-grade NEN treated by wide local resection recurred as a pulmonary metastatic nodule 8 years later [7], which was the first report of recurrent metastatic NEN of the EAC. Due to the limited number of reported EAC NENs, further study is required to ascertain its exact bio-

Table 1. Summary of seven reported cases of EAC NENs, including the present case

\begin{tabular}{|c|c|c|c|c|c|c|c|}
\hline $\begin{array}{l}\text { Case } \\
\text { No. }\end{array}$ & Study & $\begin{array}{l}\text { Age } \\
(y r) / \\
\text { Sex }\end{array}$ & Symptom & Pathologic finding & $\begin{array}{l}\text { WHO classification of NEN } \\
\text { according to 4th edition [8] } \\
\text { (NEN-2018 WHO) [9] }\end{array}$ & Treatment & $\begin{array}{l}\text { Prognosis } \\
\text { (duration of } \\
\text { follow-up) }\end{array}$ \\
\hline 1 & $\begin{array}{l}\text { Manipoud } \\
\text { et al. } \\
\text { (1994) [2] }\end{array}$ & NA & NA & NA & $\begin{array}{l}\text { Merkel cell carcinoma } \\
\text { (NEN-2018 WHO) }\end{array}$ & NA & NA \\
\hline 2 & $\begin{array}{l}\text { Litofsky } \\
\text { et al. } \\
\text { (1998) [3] }\end{array}$ & $86 / F$ & $\begin{array}{l}\text { Otalgia and } \\
\text { hearing loss }\end{array}$ & $\begin{array}{l}\text { SYN+ Vimentin+NF+CK+ } \\
\text { Chromogranin-focal+S100- } \\
\text { HMB45- GFAP- Serotonin- } \\
\text { ER- PR- }\end{array}$ & $\begin{array}{l}\text { Merkel cell carcinoma } \\
\text { (NEN-2018 WHO) }\end{array}$ & Gross total resection, RT & $\begin{array}{l}\text { No evidence of } \\
\text { recurrence } \\
\text { (8 mo) }\end{array}$ \\
\hline 3 & $\begin{array}{l}\text { Mahalingam } \\
\text { et al. } \\
(2006)[4]\end{array}$ & $32 / F$ & $\begin{array}{l}\text { Progressive } \\
\text { hearing loss }\end{array}$ & $\begin{array}{l}\text { NSE+ SYN+ PanCKweak+ } \\
\text { Chromogranin- CK20- S100- } \\
\text { HMB45- Melan A- }\end{array}$ & $\begin{array}{l}\text { NEC G1 } \\
\text { (NET G1-2018 WHO) }\end{array}$ & $\begin{array}{l}\text { Second-look } \\
\text { tympanomastoidectomy }\end{array}$ & $\begin{array}{l}\text { No evidence of } \\
\text { recurrence } \\
\text { (8 mo) }\end{array}$ \\
\hline 4 & $\begin{array}{l}\text { Palma et al. } \\
\text { (2007) [5] }\end{array}$ & $72 / \mathrm{M}$ & $\begin{array}{l}\text { Painless swelling } \\
\text { of retroauricular } \\
\text { region and } \\
\text { sudden onset } \\
\text { of bleeding }\end{array}$ & $\begin{array}{l}\text { CK perinuclear dot+ } \\
\text { Chromogranin+ NSE+ SYN+ }\end{array}$ & $\begin{array}{l}\text { Merkel cell carcinoma } \\
\text { (NEC-2018 WHO) }\end{array}$ & CTx & $\begin{array}{l}\text { Died due to } \\
\text { underlying } \\
\text { multiple } \\
\text { malignancies }\end{array}$ \\
\hline 5 & $\begin{array}{l}\text { Li et al. } \\
\text { (2012) [6] }\end{array}$ & $62 / \mathrm{M}$ & $\begin{array}{l}\text { Painless mass } \\
\text { at EAC }\end{array}$ & $\mathrm{CK}+\mathrm{NSE}+$ Vimentin+ & $\begin{array}{l}\text { Merkel cell carcinoma } \\
\text { (NEC-2018 WHO) }\end{array}$ & $\begin{array}{l}\text { Sleeve mastoidectomy and } \\
\text { tympanotomy, RT, CTx }\end{array}$ & $\begin{array}{l}\text { No evidence } \\
\text { of recurrence } \\
(2 \mathrm{yr})\end{array}$ \\
\hline 6 & $\begin{array}{l}\text { McCrary } \\
\text { et al. } \\
\text { (2017) [7] }\end{array}$ & $38 / F$ & $\begin{array}{l}\text { Otalgia, aural } \\
\text { fullness, and } \\
\text { decreased } \\
\text { hearing }\end{array}$ & $\begin{array}{l}\text { PanCK+ CD56+ SYN+ } \\
\text { Chromogranin+ CK7- Mucin- }\end{array}$ & $\begin{array}{l}\text { NEC G1 } \\
\text { (NET G1-2018 WHO) }\end{array}$ & Gross total resection & $\begin{array}{l}\text { Recurrence } \\
\text { (8 yr) }\end{array}$ \\
\hline 7 & $\begin{array}{l}\text { Present } \\
\text { case }\end{array}$ & $39 / \mathrm{M}$ & $\begin{array}{l}\text { Progressive } \\
\text { hearing loss }\end{array}$ & $\begin{array}{l}\text { SYN+ CD56+ Chromogranin- } \\
\text { CK7- CK20- }\end{array}$ & $\begin{array}{l}\text { NEC G1 } \\
\text { (NET G1-2018 WHO) }\end{array}$ & Gross total resection & $\begin{array}{l}\text { No evidence } \\
\text { of recurrence } \\
\text { (20 mo) }\end{array}$ \\
\hline
\end{tabular}

EAC, external auditory canal; NET, neuroendocrine tumor; WHO, World Health Organization; NEN, neuroendocrine neoplasm; NA, not available; NEC, neuroendocrine carcinoma; SYN, synaptophysin; NF, neurofilament; CK, cytokeratin; HMB45, human melanoma black 45; GFAP, glial fibrillary acidic protein; ER, estrogen receptor; PR, progesteron receptor; RT, radiotherapy; G1, grade 1; NSE, neuron specific enolase; CTx, chemotherapy. 
logic behavior. These seven cases are summarized in Table 1 .

Based on considerations of late recurrence and metastases despite a bland histology and a low proliferation index, complete surgical resection including complete soft tissue removal, canaloplasty, and removal of underlying bone is recommended. Prophylactic neck dissection may be recommended in neuroendocrine carcinomas of the EAC [6]. However, small, low-grade NEN may be treated by conservative surgery [7]. Chemoradiotherapy may be considered for high-grade or incompletely excised NEN. Despite limited data, consideration of patient age and physical condition, tumor staging, and histological categorization should be taken into consideration when determining treatment modalities. Additional study of NENs of the EAC is required to further understand this rare clinical entity.

Primary NENs of the EAC pose a unique diagnostic and surgical challenge. Although rare, otolaryngologist and radiologist should bear in mind metastatic NENs in the differential diagnoses of EAC masses. Here, we highlight the histologic findings of NEN of the EAC, a rare entity, and emphasize that close work up and follow up are mandatory, especially for low-grade NEN treated by wide surgical resection with or without chemoradiotherapy.

\section{ORCID}

Dong Hae Chung: https://orcid.org/0000-0002-4538-0989

Gyu Cheol Han: https://orcid.org/0000-0002-0112-8183

Na Rae Kim: https://orcid.org/0000-0003-2793-6856

\section{Author Contributions}

Conceptualization: NRK.

Data curation: NRK.

Investigation: NRK, GCH, DHC.

Resources: GCH.

Supervision: DHC.

Validation: GCH, DHC.

Writing—original draft: GCH, DHC.

Writing-review \& editing: NRK, DHC.

\section{Conflicts of Interest}

The authors declare that they have no potential conflicts of interest.

\section{Funding}

No funding to declare.

\section{REFERENCES}

1. Pelosi S, Koss S. Adenomatous tumors of the middle ear. Otolaryngol Clin North Am 2015; 48: 305-15.

2. Manipoud P, Mom T, Kemeny JL, Fouilloux G, Lafaye M. Cutaneous neuroendocrine carcinoma of the external ear canal. Ann Otolaryngol Chir Cervicofac 1994; 111: 111-4.

3. Litofsky NS, Smith TW, Megerian CA. Merkel cell carcinoma of the external auditory canal invading the intracranial compartment. Am J Otolaryngol 1998; 19: 330-4.

4. Mahalingam M, Kveaton JF, Bhawan J. Cutaneous neuroendocrine adenoma: an uncommon neoplasm. J Cutan Pathol 2006; 33: 315-7.

5. Palma S, Cavazzini L, Bovo R, et al. Merkel cell tumour of the external ear: report of a case. Auris Nasus Larynx 2007; 34: 229-32.

6. Li YK, Chi FL, Wang SY, Wang WQ, Yang JM, Huang YB. Cutaneous neuroendocrine carcinoma of the external auditory canal: a case report and review of the literature. Case Rep Otolaryngol 2012; 2012: 941065.

7. McCrary HC, Faucett EA, Reghunathan S, et al. The first reported case of recurrent carcinoid tumor in the external auditory canal. Otol Neurotol 2017; 38: 114-7.

8. Perez-Ordonez B, Bishop JA, Gnepp DR, Hunt JL, Thompson LD. Neuroendocrine tumours. In: El-Naggar AK, Chan JK, Grandis JR, Takata T, Slootweg PJ, eds. WHO classification of head and neck tumours. 4th ed. Lyon: IARC Press; 2017; 95-8.

9. Rindi G, Klimstra DS, Abedi-Ardekani B, et al. A common classification framework for neuroendocrine neoplasms: an International Agency for Research on Cancer (IARC) and World Health Organization (WHO) expert consensus proposal. Mod Pathol 2018; 31: 1770-86.

10. Sari S, Battal B, Akgun V, Salih Deveci M. Metastasis of breast carcinoma to the external auditory canal: report of an unusual case and literature review. J Belg Soc Radiol 2015; 99: 53-7.

11. Katabi N. Neuroendocrine neoplasms of the ear. Head Neck Pathol 2018; 12: 362-6.

12. Xu B, Chetty R, Perez-Ordoñez B. Neuroendocrine neoplasms of the head and neck: some suggestions for the new WHO classification of head and neck tumors. Head Neck Pathol 2014; 8: 24-32.

13. Bell D, El-Naggar AK, Gidley PW. Middle ear adenomatous neuroendocrine tumors: a 25-year experience at MD Anderson Cancer Center. Virchows Arch 2017; 471: 667-72. 